\title{
Article \\ Understanding Smallholder Farmers' Intention to Adopt Agricultural Apps: The Role of Mastery Approach and Innovation Hubs in Mexico
}

\author{
Janet Molina-Maturano $^{1, *(\mathbb{D})}$, Nele Verhulst ${ }^{2} \mathbb{D}$, Juan Tur-Cardona ${ }^{1}$, David T. Güereña ${ }^{2,3} \mathbb{D}^{\text {, }}$ \\ Andrea Gardeazábal-Monsalve ${ }^{2}$, Bram Govaerts ${ }^{2,4}$ (D) and Stijn Speelman ${ }^{1}$ \\ 1 Department of Agricultural Economics, Faculty of Bioscience Engineering, Ghent University, \\ 9000 Ghent, Belgium; juan.turcardona@ugent.be (J.T.-C.); Stijn.Speelman@UGent.be (S.S.) \\ 2 International Maize and Wheat Improvement Center (CIMMYT), El Batán, Texcoco 56237, Mexico; \\ N.Verhulst@cgiar.org (N.V.); D.GUERENA@cgiar.org (D.T.G.); A.GARDEAZABAL@cgiar.org (A.G.-M.); \\ b.govaerts@CGIAR.ORG (B.G.) \\ 3 Platform for Big Data Agriculture, The Alliance of Bioversity and the International Center for Tropical \\ Agriculture (CIAT), The Americas Hub, Cali 763537, Colombia \\ 4 Cornell University, Ithaca, NY 14853, USA \\ * Correspondence: Janet.MolinaMaturano@UGent.be
}

check for updates

Citation: Molina-Maturano, J.; Verhulst, N.; Tur-Cardona, J.; Güereña, D.T.; GardeazábalMonsalve, A.; Govaerts, B.; Speelman, S. Understanding Smallholder Farmers' Intention to Adopt Agricultural Apps: The Role of Mastery Approach and Innovation Hubs in Mexico. Agronomy 2021, 11, 194. https://doi.org/10.3390/ agronomy11020194

Received: 14 December 2020

Accepted: 15 January 2021

Published: 20 January 2021

Publisher's Note: MDPI stays neutral with regard to jurisdictional claims in published maps and institutional affiliations.

Copyright: (c) 2021 by the authors. Licensee MDPI, Basel, Switzerland. This article is an open access article distributed under the terms and conditions of the Creative Commons Attribution (CC BY) license (https:// creativecommons.org/licenses/by/ $4.0 /)$.

\begin{abstract}
While several studies have focused on the actual adoption of agricultural apps and the relevance of the apps' content, very few studies have focused on drivers of the farmer's intention and initial decision to adopt. Based on a survey of 394 smallholder farmers in 2019, this study investigated willingness to adopt an agricultural advice app in Guanajuato, Mexico. A structural equation modeling approach, based on the unified theory of acceptance and use of technology (UTAUT), was applied. To understand the farmers' adoption decisions, extended constructs were studied (e.g., mastery-approach goals) along with the farmers' age and participation in an innovation hub. Results showed that the intention to adopt the app is predicted by how farmers appraise the technical infrastructure and acquire new knowledge by using an app. The multi-group analysis revealed that performance expectancy is a relevant predictor of the intention to adopt, whereas the mastery-approach goal is relevant only for younger farmers and farmers not connected to the innovation hub. This study provides valuable insights about the innovation hubs' role in the intention to adopt apps, offering precision agriculture advice in developing countries. The findings are useful for practitioners and app developers designing digital-decision support tools.
\end{abstract}

Keywords: structural equation modelling; smallholder farmers; smartphone apps; decision-support systems; unified theory of acceptance and use of technology; innovation hubs; mastery-approach goal

\section{Introduction}

There is an increasing interest in literature that identifies the use of emerging technologies in precision agriculture to efficiently increase production while reducing its environmental impacts [1]. Precision agriculture is a management strategy that uses electronic information and other technologies to gather, process, and analyze spatial and temporal data for the purpose of guiding targeted actions that improve site-specific crop management, productivity, and sustainability of agricultural operations [2,3]. Typically, precision agriculture relies upon new technologies such as smart sensors, drones, artificial intelligence (AI), the Internet of Things (IoT), or blockchain [4]. Smartphone apps also play an increasing role in this [5]. Based on these technologies, it has become possible to process and access real-time data about the conditions of the soil, crops, and weather, along with other relevant services such as crop and fruit supply chains, food safety, and animal grazing. However, precision agriculture has shown an uneven success, with greater adoption in developed countries and among large-scale farms $[2,6]$. While GIS and remote sensors have 
been the key transformational driver on large farms, mobile phones and their ubiquity are predicted to bring similar transformational potential to small-scale farmers $[7,8]$.

Smartphone applications can provide farmers with easy access to tailor-made relevant information to inform their decisions to increase crop yields, protect their land and water resources, and improve their livelihoods $[9,10]$. The adoption of mobile-phone technologies by farmers also promises to collect more comprehensive, relevant, and accurate agricultural data [11,12]. Moreover, crowdsourcing and citizen-science applications offer solutions for simultaneous provision of affordable decision support systems (DSS) to smallholder farmers while collecting agricultural data $[13,14]$. However, uptake by farmers and advisers of DSS and mobile-phone apps are still low [15]. Among others, challenges of low uptake relates to financial barriers, infrastructure, gaps among developers and end-user information needs, and a lack of understanding of farmers' profiles in the local context [15-17]. Previous recommendations to effectively promote DSS design and delivery are found in academic literature in the UK [15] or generated by private consortiums such as the GSMA mAgri Design Toolkit for developing countries [18]. However, other geographical regions and realities similar to rural areas in Central and Latin America remain understudied [19].

Moreover, where adoption does occur, not all farmers adopt information and communication technologies (ICTs) in the same manner [20], nor are farmers' motivations the same in all settings [14]. While current studies have focused on smartphone adoption by farmers in African countries [21,22] and on advice-delivery tools for smallholder farmers in India [23], only a few have focused on the initial adoption decision. The actual adoption is normally studied at late stages of an app's development, or after an intervention using ICT for development. In contrast, studying the intention to adopt during early stages of an app's development might provide early feedback towards enabling user-centeredness [24]. The drivers of farmers' initial adoption of agricultural information apps are less studied than those of apps offering financing or health services [25]. One exception was a study that looked at the initial adoption of smartphone apps for crop protection in Germany. However, more research is needed in developing and emerging countries [19]. Therefore, we investigated the factors affecting the initial uptake of an agricultural app by Mexican smallholder farmers. This is highly relevant because Mexico is a region with a viable ecosystem of ICT innovations in the agricultural sector due to mobile-phone apps being developed by government agencies to connect farmers with buyers or obtain advice on crop production. In addition, B-corporations such as the Extensio platform (previously Esoko) were launched in 2015 to provide content to Mexican farmers through SMS, a call center, and a smartphone app. Furthermore, reflecting on the extension experience and large datasets of the International Maize and Wheat Improvement Center (CIMMYT), the AgroTutor app is a mobile phone app that provides information to smallholder farmers about maize and wheat and related topics, including weather, grain and input prices, benchmarking, agronomic recommendations, and potential yield [26].

To gain a better understanding of farmers' initial adoption decision, this study applied the unified theory of acceptance and use of technology (UTAUT) introduced by Venkatesh et al. [27]. The UTAUT considers the behavioral factors of "performance expectancy" (PE), "effort expectancy" (EE), "social influence" (SI), and "facilitating conditions" (FC). Based on a fieldwork survey conducted in 2019 of 394 farmers, the model for the UTAUT is estimated using structural equation modeling (SEM). While current studies have focused on farmers general willingness to pay for smartphone apps (that give, for example, crop-protection advice), none have focused on the intention to adopt such technology in developing countries [11].

Therefore, the novelty of this article is twofold. Firstly, this is the first study that explicitly focused on smallholder farmers' initial decision to adopt an agricultural app in Mexico. Specifically, this study adds to the literature by examining if the UTAUT enriched with additional constructs can contribute to the understanding of the underlying behavioral factors influencing the farmers' initial adoption decision. In this way, we are able to explore the effect of smallholder farmers' motivation to learn and explore new technologies and 
their perception of the app during the initial decision to adopt. Extending the UTAUT constructs offers two interesting notions: (i) a baseline of farmers' intrinsic motivation (why they are motivated to use it); and (ii) behavioral factors influencing the intention to adopt (how the app is being perceived). Second, this is the first study to consider the role of connectedness to an innovation hub in the farmers' intention to adopt a smartphone app developed by a non-profit research-for-development organization (vs. commercial for-profit apps). One important contribution by this study is to increase our understanding of the innovation hubs' effect on the intention to adopt such apps specifically in developing countries. The results are of interest for decision-makers in digitalization, app developers, and project managers. The results provide insights on ways to encourage adoption of noncommercial (free) agricultural apps that provide affordable precision agriculture services (e.g., site-specific advice, weather information, yield forecast) that complement the work of extension agents in the field. Additionally, the results elucidate the smallholders' adoption drivers of apps that provide commodity price forecasts and financial benchmarking, while encouraging them to contribute with in-situ information about soil management and yield data [18].

\section{Theoretical Framework and Research Model}

The unified theory of acceptance and use of technology (UTAUT) aims to explain usage behavior, such as the intention to adopt a mobile phone app [27], and has been empirically validated in diverse disciplines [28]. It is the theoretical basis for our study. The model, which is based on eight prominent user-adoption models, was later extended into the UTAUT2 by adding three constructs (hedonic motivation, price value, and habit) [29]. However, UTAUT2 constructs are not included in this work, since the focus is on the initial adoption rather than actual use. The hypotheses concerning the relationships between the proposed factors of the farmers' behavioral intention (BI) are outlined in Figure 1.

Performance Expectancy (PE)

UTAUT Facilitating Conditions (FC)

Constructs Effort Expectancy (EE)

$\begin{array}{cl} & \text { Social Influence (SI) } \\ & \\ \text { New } & \text { Mastery-approach goals (MAG) } \\ \text { constructs } & \text { Personal Innovativeness in IT (IN) } \\ & \text { Trust (TR) }\end{array}$

\section{Moderators Variables}

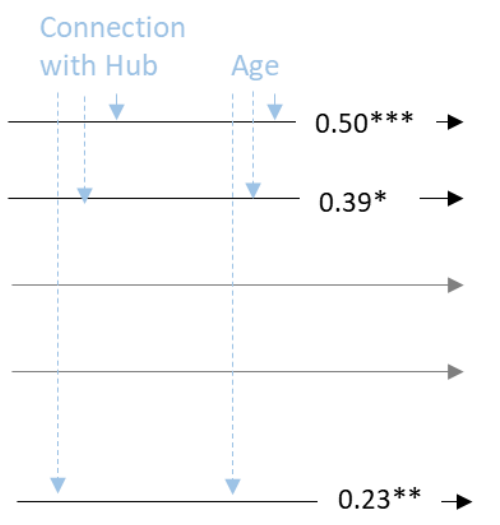

\section{Behavioural} Intention (BI)

Figure 1. PE, FC, and MAG affect farmers' willingness to adopt an agricultural-information app. The blue items show the moderation effect of "connection to an innovation hub" on PE, FC, SI, and MAG. MAG was not in the original UTAUT model. Significance codes: ${ }^{*}$ at $p<0.05,{ }^{* *}$ at $p<0.01,{ }^{* * *}$ at 0.001 .

"Performance expectancy" is the degree to which using a technology will provide benefits to the individuals using it [27]. In this study, it refers to the degree to which a farmer believes that accessing agriculture-related information through a mobile-phone app will benefit her/his farming activities. One attractive feature of an agricultural app is the ability it gives farmers to access accurate local information anywhere, at any time, without wasting productive time. Therefore, we hypothesized that: 
Hypothesis 1 (H1). Performance expectancy (PE) positively affects behavioral intention (BI) to use a mobile-phone app.

"Facilitating conditions" refers to the extent to which farmers believe that technical infrastructure exists to help them to use a technology whenever necessary [29]. Using a mobile-phone app requires certain skills, such as being able to operate a mobile phone, download the app, and navigate the content. A farmer who shares a household with an educated person or has access to facilitating conditions, such financial resources, will have a greater intention to use. Therefore, we hypothesized that:

Hypothesis 2 (H2). Facilitating conditions (FC) positively affect behavioral intention (BI) to use a mobile-phone app.

"Effort expectancy" is the degree of ease associated with farmers' use of a technology [29]. In the case of an app, some farmers might be more literate than others in ICT-based technologies, and would accordingly be expected to have fewer problems using a mobile phone to access agricultural or crop information. It is expected that farmers who are easily able to obtain and interpret relevant information using a mobile-phone app would be more willing to use it, and therefore we hypothesized that:

Hypothesis 3 (H3). Effort expectancy (EF) positively affects behavioral intention (BI) to use a mobile-phone app.

"Social influence" is the extent to which farmers perceive that important people believe they should use a particular technology [29] such as a mobile-phone app. The primary assumption is that individuals tend to consult their social network, especially friends and family, about new technologies, and can be influenced by perceived social pressure of important people. It could be particularly important in explaining an initial adoption [30]. Therefore, we hypothesized that:

Hypothesis 4 (H4). Social influence (SI) positively affects behavioral intention (BI) to use a mobile-phone app.

Additional constructs include personal innovativeness in IT, mastery-approach goals, and trust. In this study, the mastery-approach goal orientation (MAG) and personal innovativeness in information technology (IN) constructs were added to the UTAUT framework. These new constructs are proposed as a pathway to measure the intrinsic motivations based on an existing incentive to learn. Acquiring new skills and knowledge has been shown [11] to act as an incentive to adopt a new technology. The addition of the trust (TR) construct was proposed to explore the role of the extension services (as providers and disseminators of the app technology) and the enabling environment in which an app is being pilot-tested.

Researchers have recently suggested "attitude" as a mediator of the intention to adopt [31]. However, MAG and IN are specific to IT technologies, and are suitable in the case of an agricultural app aimed at the exchange of information. We will present a detailed description of the theories on which the constructs are based, as well as the rationale to select them in the present model.

The diffusion of innovation theory (DIT) is an extensive social and psychological notion that attempts to predict how individuals make decisions to adopt a new innovation [32,33]. The concept was adapted by Agarwal and Prasad [34], who proposed a new construct to measure personal innovativeness as "the willingness of an individual to try out any new IT." Since farmers that participated in this study do not have experience in using precision agriculture tools (e.g., tailored cultivation advice) through mobile-phone apps, we have included the IN construct in our model (Figure 1). Moreover, the DIT has shown that highly innovative individuals actively seek information about new technologies or 
ideas. They are able to cope with high levels of uncertainty, and are more favorably inclined to accept a technology [32]. This leads to the following hypothesis:

Hypothesis 5 (H5). Personal innovativeness in information technology (IN) positively affects behavioral intention (BI) to use a mobile-phone app.

Even though trust can be understood as a subjective belief, its effect as a construct on behavioral intention has gained support in the context of UTAUT and mobile payments (mpayments) explored along with risk [35-38]. In contrast with Beza [39], this work explored trust concerning the app provider (or promoter) rather than trust in the tool or project. Then trust (TR) is defined as the extent to which the mobile-phone app provider(s) is believed to want to do good for the farmer, apart from selfish motives. If a farmer believes the mobile-phone app promoters (e.g., extension agents) care about his/her interests, the mobile phone app provider is seen as displaying benevolence toward the farmer [40]. The probability of farmers sharing their agronomic information is highly dependent on the trustworthiness of the party (i.e., "trustees" such as agronomic experts, researchers, and research institutes). Hence, we formulated the following hypothesis:

Hypothesis 6 (H6). Trust (TR) positively affects behavioral intention (BI) to use a mobilephone app.

As most farmers do not have experience in the use of these types of mobile-phone apps, experience was not included as a moderator. Instead, we hypothesize that the connection with the innovation hub brokered by CIMMYT in Guanajuato (Section 3.1) moderates the effects of UTAUT constructs and additional constructs due to the development of a conducive environment for innovation and decision-making.

Finally, the MAG is based on the goal orientation theory, which articulates that the main goal people can pursue while performing a task is that of mastery [41], and to understand something new or to improve their level of know-how [42]. The MAG has been extensively explored in the context of learning and education [43]. The livelihoods of most smallholder farmers depend on farming, so they will always look for new methods, skills, and knowledge to improve agricultural productivity. Farmers with a mastery goal will be expected to use the mobile-phone app to acquire new skills and knowledge, leading to the following hypothesis:

Hypothesis 7 (H7). A mastery goal orientation positively affects behavioral intention (BI) to use a mobile phone app.

In addition, sociopsychological research relates farmers' intrinsic motivation to the decision to participate in extension/education activities such as motivational orientation [44] This is an interesting proposition to explore the links between farmers' motivation to learn and explore new technologies and the farmers' perception of the app and its context.

We hypothesize that age moderates the effects of UTAUT constructs (PE, EE, SI, FC) on behavioral intention $[27,29]$. The effects of effort expectancy (EE) and facilitating conditions (FC) on behavioral intention are expected to be stronger for older farmers. The effect of performance expectancy (PE) is expected to be stronger for younger farmers, while the effect of social influence (SI) is expected to be stronger for older and experienced farmers. The added constructs (IN, TR, MAG) could also be influenced by age and connection to an innovation hub, but only MAG was included in the multigroup analysis, as we explain below.

\section{Materials and Methods}

\subsection{Research Context}

The study area of the state of Guanajuato is divided in 46 municipalities, with 5.8 million inhabitants in total Agriculture is important in the Mexican state of Guanajuato, with 
$31 \%$ of its area dedicated to agriculture [45]; areas such as the Bajío region are important for agriculture and livestock. Around $85 \%$ of its harvested area is sown to beans and cereal grains, including sorghum, wheat, maize, and barley [46,47]. Guanajuato had the highest agricultural production in the country in 2019, with sorghum yields barely at the national level and the second-highest yields for wheat $(6.8 \mathrm{t} / \mathrm{ha})$, following the state of Sonora $(6.9 \mathrm{t} / \mathrm{ha})$. At nearly $12 \mathrm{t} / \mathrm{ha}$, the state's average maize yields are among the highest in Mexico [48,49].

CIMMYT has been working on innovation in agri-food systems in Mexico for the past decade, funded through partnerships with several actors, of which the Government of Mexico has been the largest funder, both at the federal level through the Ministry of Agriculture and at the state level in Guanajuato. Work takes place through 12 innovation hubs located strategically throughout Mexico; the hubs seek to integrate farmers and local and regional value-chain actors for maize- and wheat-based farming systems [35]. This study builds on the work in the hub in Guanajuato. The hubs comprise research platforms, demonstration modules, and extension and impact areas. The research platforms are carrying out joint research with local institutes, as well as generating and sharing new knowledge, and adapting farming innovations for their specific areas. The demonstration modules are on farmers' land and involve side-by-side fields managed using new technologies or conventional practices for comparison. Module outcomes are often fed back to research platforms and allow for farmer-to-farmer interaction and sharing, with the aim to drive adoption, to have local impacts, and to scale useful innovations. Extension areas are parcels where farmers have applied knowledge from demonstration modules. Impact areas are defined as places where farmers who are not directly connected to the hubs have adopted the program's innovations [45].

Created in 2017 by the International Institute of Applied Systems Analysis (IIASAAustria) and currently in a second phase of development, the AgroTutor mobile-phone application is a pilot project of CIMMYT (Figure 2) that is being tested in Guanajuato, Mexico. The app provides farmers with access to best practices and geo-referenced and timely information about fields and crops, including benchmarking data for crop placement, timely agronomical recommendations (i.e., optimizing use of fertilizers), potential yield and financial benchmarking information (i.e., prices and costs), historical and forecasted weather data, and other expert sources of agricultural information in the region. Farmers can also provide their own information regarding soils, management, and yields for use in crop models and for generating improved recommendations [26]. The intended target group is smallholder farmers who can consult the app during different phases of maize and wheat cultivation, especially farmers in a decision-making process of applying sustainable agriculture practices who are searching for both technical information and yield forecasts. In addition, the app is expected to be used as a complementary tool for extension agents to encourage collection of in-situ data of soils and yield by farmers.

\subsection{Data Collection, Sampling, and Measurement Tool}

In 2019, we conducted a survey through face-to-face interviews with farmers in the El Bajío region of Guanajuato using the GeoODK mobile phone app, an open-source tool. A database (2014-2019) of presumably active farmers in the innovation hub containing their correspondent municipalities was used to select the respondents in two stages. First, respondents that were connected to the hub were randomly selected from the mentioned database. In some cases, we learned that the farmer passed away or could not be reached after several attempts. Then, another farmer who connected to the innovation hub in the same municipality was surveyed. Two municipalities were removed from the sampling frame due to security issues resulting from increased drug-cartel activity in the region. The second stage of the sampling comprised farmers not connected to the innovation hub, in the same municipalities, approached at meeting points (while they were waiting in a queue) or before events in the region (e.g., association, presentation of agricultural products, etc.). Around one out of two non-connected farmers who were approached agreed to take 
the survey. Therefore, a similar number of non-connected farmers were approached and interviewed in the same municipalities (Figure 3). A total of 394 responses were obtained (205 from MasAgro-connected farmers and 189 from non-connected farmers), with no missing values. We obtained prior informed verbal consent from all respondents, and no personal data were gathered.

\section{Farmers can consult targeted benchmarking information:}

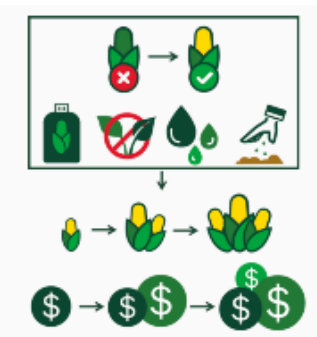

Benchmarking information details are specific to your plot location and the crop planted. The recommendations focus on optimizing use of fertilizer and other inputs to maximize yield and profit
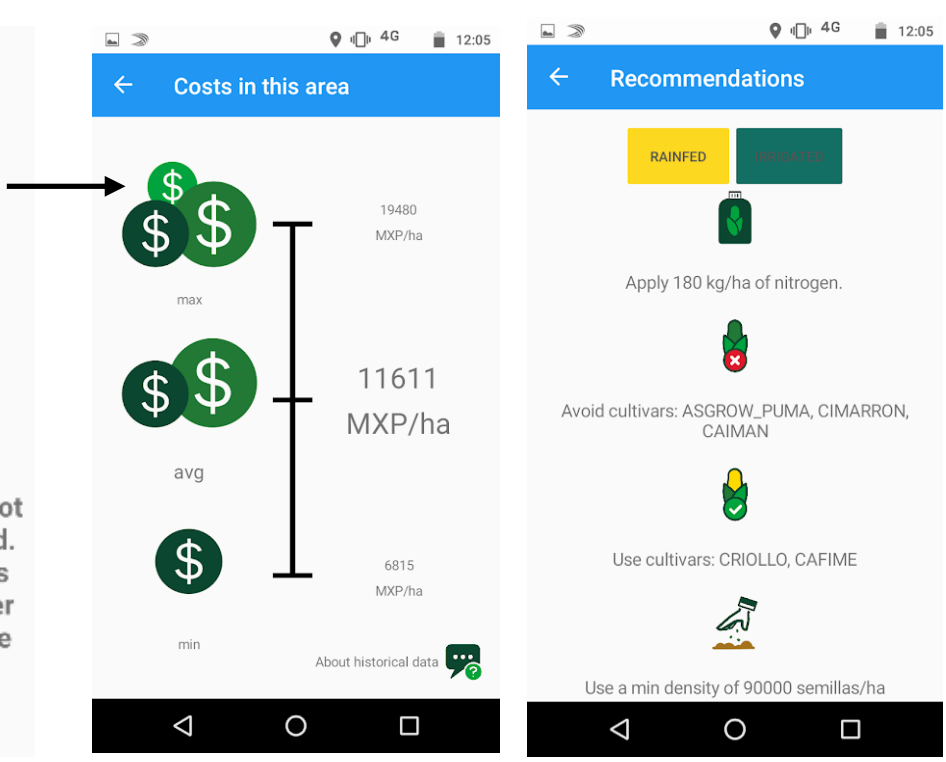

Use a min density of 90000 semillas/ha

$\triangleleft$ $\square$

\section{Farmers can geo-locate, register plots and agricultural activities}
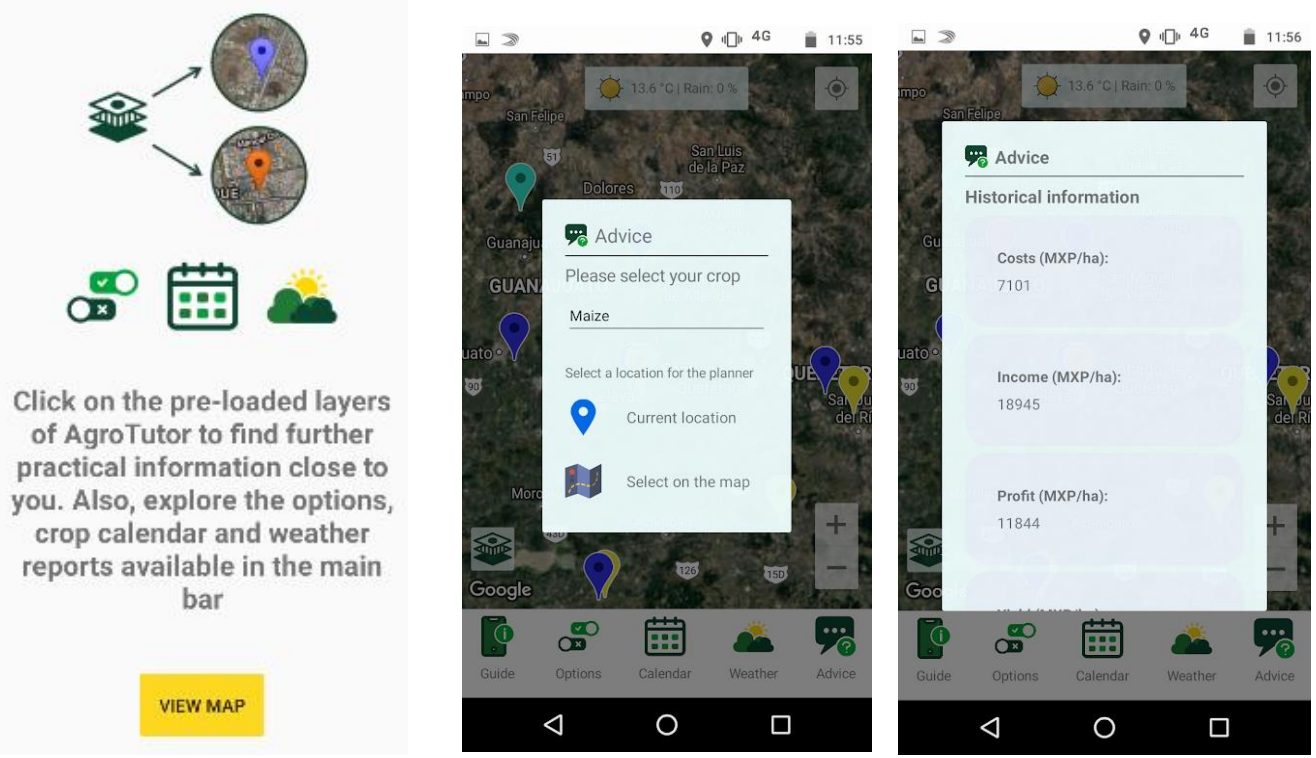

Figure 2. The AgroTutor app with main activities (extracted from AgroTutor website and Technical Note [26]). 


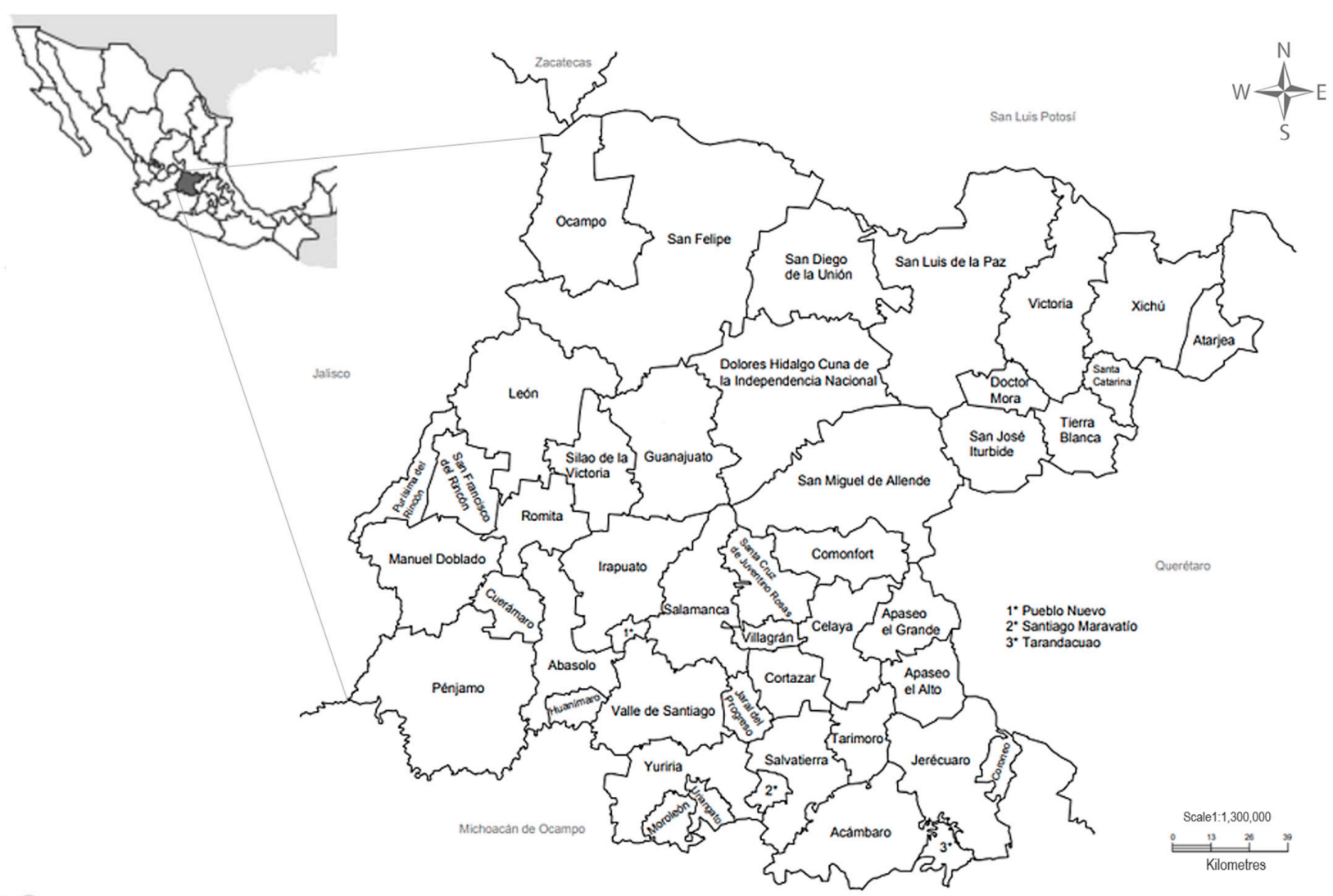

Figure 3. The study area. Source: INEGI. Geostatistical Framework, 2018. Adapted from https://imagenestotales.com/ mapa-guanajuato-municipios/ website.

Farmers were surveyed using standardized questions based on Beza [39] and Venkatesh [27], with sections covering general information and demographic characteristics, their history of use of mobile phones to access agronomic data and recommendations, and questions of the model used. An introductory text made clear that the questions were related to the potential use of a mobile-phone app to access agricultural data (Appendix A). All farmers viewed a short video describing the app and its salient features prior to responding to the measurement items. Each construct was based on three to five items, as recommended by Hair [50]. A total of 30 measurement items adapted from prior studies (Appendix B) were carefully rephrased in the context of an agriculture-related mobile-phone app, with response selections on a seven-point Likert scale ranging from "Totally disagree" (1) to "Totally agree" (7). Appendix B contains all the references from previous studies for each construct. The surveys were pilot-tested with at least 10 farmers, extension agents, and enumerators (Appendix A-Questionnaire).

\subsection{Estimation Techniques and Data Analysis}

Statistical analyses were performed using the lavaan R package [51] and SPSS. Demographic data were first analyzed using descriptive statistics. Then a structural equation Modeling (SEM) was conducted to test the model presented in Figure 1. A structural equation model is a set of statistical models that seek to explain the relationships between multiple variables; it was used because it allows the simultaneous analysis of all relationships, combining multiple regression with factor analysis, while allowing for both observed and latent variables to be analyzed together [50]. First, a confirmatory factor analysis (CFA) was conducted using a maximum likelihood estimation to examine the reliability and validity of our measurement model. Second, we evaluated the path analysis of the structural model estimates to test the significance of our hypotheses and the predictive items of the proposed model. Prior to assessing the measurement and structural 
models, common method variance (CMV) and multicollinearity were tested. To check for a common method bias, the Harman [45] single-factor test was employed iteratively in SPSS. The results showed that all factor(s) accounted for $<50 \%$ of the variance. Hence, no factor was found to account for most of the variance in the variables, confirming that the common method variance was not a concern in the data. To test multicollinearity, variance inflation factors (VIFs) and tolerance were computed in R for the constructs, and they were found to be less than the threshold of 5 and greater than 0.1 , respectively, suggesting that multicollinearity was not a major issue in our study [50].

The general fit of the measurement and structural models were assessed using a combination of absolute and relative indices: the normed chi-square (CMIN/DF), the adjusted goodness-of-fit index (AGFI), the comparative fit index (CFI) or the Tucker-Lewis index (TLI), and the root mean square error of approximation (RMSEA). For both the measurement and structural models to have a sufficiently good fit, based on the sample size, these measurements needed to be $<3, \geq 0.8, \geq 0.92$ or 0.94 , and $\leq 0.7$, respectively $[50,52]$. For the structural model, the strength and significance of the relationship between each of the constructs and the behavioral intention were assessed using standardized regression weights (SRW) and $p$-value $(p<0.05)$. Prior to the path analysis (hypotheses-testing), the measurement model was also assessed for (i) construct reliability, (ii) indicator reliability, (iii) convergence validity, and (iv) discriminant validity. Construct reliability is a measure of the internal consistency of the measurement items and was assessed using composite reliability (CR) and Cronbach's alpha values [50]. The indicator reliability was evaluated based on factor loadings. Convergence validity measures whether items can effectively reflect their corresponding construct (i.e., converge on the intended construct), whereas discriminant validity measures whether two constructs are statistically and theoretically different [50]. The average variance extracted (AVE) was used as the criterion to assess convergence validity [53]. To examine discriminant validity, we used the heterotrait-monotrait ratio (HTMT) computed using lavaan in R [51].

Finally, we conducted a multi-group analysis to assess the moderation effect of a farmer's age between UTAUT constructs and behavioral intention (Figure 1). For the factor 'age,' respondents were divided into two groups, based on the average age in the sample. Farmers under the median age of 55 years old $(n=201)$ were grouped as younger farmers and those 55 years or older $(n=193)$ were designated as older farmers. 'Gender' as moderator variable in the UTAUT model was not further considered because very few female farmers participated in the study. As part of the analysis, measurement model invariance, which includes configural and metric invariance, was assessed following the three-step procedure presented in Steenkamp and Baumgartner [54]. Configural invariance checks if the factor structure is invariant across groups, indicating that participants from the different groups understand the constructs in the same way [55]. Metric invariance tests if different groups respond to the items in the same way. That is, it checks if the strengths of the relationships between specific items and their respective underlying construct (i.e., factor loadings) are the same across groups [55]. A detailed procedure on how to assess configural and metric invariance can be found in Appendix C. Fit indices for the fully constrained measurement model between younger and older farmers (CMIN/DF $=2.169$; $\mathrm{CFI}=0.932$; RMSEA $=0.077$ ), and between connected and non-connected farmers (CMIN/ $\mathrm{DF}=2.367 ; \mathrm{CFI}=0.926 ; \mathrm{RMSEA}=0.083 ; \mathrm{SRMR}=064$ ) were satisfactory. The results of the partial constrained measurement models were compared to those of the unconstrained multigroup measurement models using a chi-square difference test. The chi-square difference test for the two groups was not significant, suggesting that partial metric invariance for the two groups was also met, following Milfont and Fischer [55]. After assessing the criteria for both configural and partial metric invariance at the measurement model level, an invariance analysis at the structural model level was conducted (Appendix C). 


\section{Results and Discussion}

\subsection{Descriptive Statistics}

The characteristics of the farmers surveyed in this study are presented in Table 1a. Most respondents were male (94\%), and 69\% of the respondents were between 41 and 70 years old. This age distribution is in line with a national survey by INEGI in 2017 [56]. Most respondents owned a mobile phone (82\%), and $37 \%$ had started using a smartphone in the past five years (Table 1b).

Table 1. (a) Demographic characteristics of the surveyed farmers; (b) Distribution of mobile phone ownership and use by surveyed farmers.

\begin{tabular}{|c|c|c|}
\hline & (a) & \\
\hline Factor & Frequency (394) & Percentage (\%) \\
\hline \multicolumn{3}{|l|}{ Gender } \\
\hline Male & 370 & 93.9 \\
\hline Female & 24 & 6.1 \\
\hline \multicolumn{3}{|l|}{ Age (years) } \\
\hline $16-30$ & 17 & 4.3 \\
\hline $31-40$ & 48 & 12.2 \\
\hline $41-50$ & 74 & 18.8 \\
\hline $51-60$ & 112 & 28.4 \\
\hline $60-70$ & 86 & 21.8 \\
\hline 71 or older & 57 & 14.5 \\
\hline \multicolumn{3}{|l|}{ Educational level } \\
\hline none & 48 & 12.2 \\
\hline Primary school & 140 & 35.5 \\
\hline Secondary school & 130 & 33.0 \\
\hline Higher education & 76 & 19.3 \\
\hline \multicolumn{3}{|l|}{ Marital status } \\
\hline Single & 53 & 13.5 \\
\hline Married & 336 & 85.3 \\
\hline \multirow[t]{2}{*}{ Cohabitation } & 5 & 1.3 \\
\hline & (b) & \\
\hline Factor & Frequency (394) & Percentage (\%) \\
\hline \multicolumn{3}{|l|}{ Own a mobile (all types) } \\
\hline Yes & 324 & 82.2 \\
\hline smartphone & 181 & \\
\hline feature phone & 66 & \\
\hline basic & 77 & \\
\hline No & 70 & 17.8 \\
\hline \multicolumn{3}{|l|}{ Years of using a smartphone } \\
\hline $0-5$ years & 147 & 37.3 \\
\hline $6-10$ years & 30 & \\
\hline $11-15$ years & 4 & \\
\hline
\end{tabular}

The INEGI survey reported that at a national level, 33\% of the production units use information and communication technology for agricultural activities. Of the INEGIsurveyed production units, $90 \%$ had a cell phone/mobile phone. For Guanajuato, it was reported that $50 \%$ use ICT, and $90 \%$ of the production units own a mobile phone [57]. This is comparable with the $82 \%$ observed in our sample (Table $1 \mathrm{~b}$ ).

\subsection{Evaluation of the Measurement Model}

The first fit of the measurement model that included all the items of the constructs was sufficient. The model fit indices resulted in a "good measurement model" [50] with the following index values: CMIN/DF: 2.577; AGFI: 0.823; CFI: 0.941; and RMSEA: 0.063 
(Table 2). The measurement model assessment of (i) construct reliability, (ii) indicator reliability, (iii) convergence validity, and (iv) discriminant validity is shown in Table 3. All the constructs showed composite reliability (CR) and Cronbach's alpha values greater than 0.7 , indicating that the construct's reliability criterion was met [50]. The factor loadings for all items were greater than the threshold value of 0.7 , confirming a good indicator reliability of the instrument (Table 3). No items needed to be dropped due to low factor loading. The convergence validity was tested with the average variance extracted (AVE) value [53], and all the constructs had an AVE greater than the minimum acceptable value of 0.5 , confirming the convergence validity criterion was achieved.

Table 2. Summary of fit indices for the measurement and structural models.

\begin{tabular}{|c|c|c|c|}
\hline Model Fit Indices & $\begin{array}{l}\text { Recommended } \\
\text { Value }\end{array}$ & Model Results & Reference \\
\hline $\begin{array}{l}\text { Normed chi-square } \\
\text { (CMIN/DF) }\end{array}$ & $<3$ & 2.58 & {$[50,52]$} \\
\hline $\begin{array}{l}\text { Comparative fit index } \\
\text { (CFI) }\end{array}$ & Above 0.92 or 0.94 & 0.933 & {$[50,52]$} \\
\hline TLI (Tucker-Lewis index) & Above 0.92 or 0.94 & 0.932 & {$[50]$} \\
\hline RNI & Above 0.90 & 0.941 & {$[50]$} \\
\hline SRMR & $\begin{array}{c}0.09 \text { or less (with CFI } \\
\text { above } 0.92 \text { ) }\end{array}$ & 0.052 & {$[50]$} \\
\hline $\begin{array}{l}\text { Root mean square error } \\
\text { of approximation } \\
\text { (RMSEA) }\end{array}$ & $\begin{array}{l}\text { Value }<0.08 \text { (with } \\
\text { CFI of } 0.92 \text { ) }\end{array}$ & 0.063 & {$[50,52]$} \\
\hline $\begin{array}{l}\text { Adjusted goodness-of-fit } \\
\text { index (AGFI) }\end{array}$ & $\geq 0.8$ & 0.823 & [50] \\
\hline
\end{tabular}

Table 3. Summary of reliability and validity measures of the measurement model.

\begin{tabular}{cccccc}
\hline Construct & $\begin{array}{c}\text { Number of } \\
\text { Items }\end{array}$ & $\begin{array}{c}\text { Composite } \\
\text { Reliability } \\
\text { (CR) }\end{array}$ & $\begin{array}{c}\text { Cronbach's } \\
\text { Alpha }\end{array}$ & AVE & $\begin{array}{c}\text { Factor } \\
\text { Loadings }\end{array}$ \\
\hline BI & 3 & 0.916 & 0.915 & 0.786 & $0.850-0.905$ \\
PE & 4 & 0.898 & 0.896 & 0.687 & $0.787-0.851$ \\
EE & 4 & 0.932 & 0.931 & 0.774 & $0.843-0.902$ \\
FC & 4 & 0.836 & 0.825 & 0.570 & $0.621-0.835$ \\
SI & 4 & 0.884 & 0.882 & 0.656 & $0.800-0.825$ \\
TR & 5 & 0.926 & 0.925 & 0.714 & $0.770-0.887$ \\
MAG & 3 & 0.913 & 0.913 & 0.777 & $0.867-0.895$ \\
IN & 3 & 0.846 & 0.842 & 0.646 & $0.685-0.883$ \\
\hline
\end{tabular}

Discriminant validity can be derived from the data in Table 4, in which the matrix shows the HTMT values between each pair of factors, which were all below 0.9 . The overall results indicated that the model had good indicator and construct reliability, and good convergence and discriminant validity, confirming that the constructs were statistically distinct and could be used to test the path analysis of the structural model. 
Table 4. A matrix showing the HTMT values between each pair of factors.

\begin{tabular}{ccccccccc}
\hline & BI & PE & EE & FC & SI & TR & MAG & IN \\
\hline BI & 1 & & & & & & & \\
PE & 0.845 & 1 & & & & & & \\
EE & 0.629 & 0.547 & 1 & & & & & \\
FC & 0.792 & 0.651 & 0.878 & 1 & & & & \\
SI & 0.709 & 0.695 & 0.551 & 0.728 & 1 & & & \\
TR & 0.483 & 0.457 & 0.386 & 0.484 & 0.617 & 1 & & \\
MAG & 0.795 & 0.687 & 0.536 & 0.770 & 0.794 & 0.532 & 1 & \\
IN & 0.741 & 0.681 & 0.561 & 0.707 & 0.786 & 0.602 & 0.795 & 1 \\
\hline
\end{tabular}

\subsection{Path Analysis Estimation and Results}

After assessing the measurement model, the structural model (path analysis) was assessed. The overall model fit for the structural model was good (Table 2). Values for the indices CMIN/DF, CFI, TLI, RNI, SRMR, RMSEA, and AGFI were nearly the same as the measurement model. The path analysis showed that three hypotheses were supported (Table 5). Significant positive impacts on behavioral intention (BI) were found for performance expectancy (PE) (confirming H1), facilitating conditions (FC) (confirming H3), and mastery-approach goals (MAG) (confirming H6). The two factors from the UTAUT model explained $25 \%$, while adding the construct of mastery-approach goals increased this to $39.5 \%$ of the variance in farmers' intention to adopt the app. Among the tested constructs (apart from the UTAUT), the mastery-approach goals (H6) had a significant impact on the intention to adopt the mobile-phone app, indicating that farmers believed that mastering the use of an app might help them to improve their level of competence and knowledge of agriculture [56].

Table 5. Summary of the results of the path analysis of the structural model.

\begin{tabular}{ccccc}
\hline \multirow{2}{*}{ Hypothesis } & Structural Path & \multicolumn{2}{c}{ Estimates } & \multirow{2}{*}{ Result } \\
\cline { 3 - 4 } & & SRW & $p$-Value & \\
\hline $\mathrm{H} 1$ & $\mathrm{PE} \rightarrow \mathrm{BI}$ & 0.500 & $0.00^{* * *}$ & Supported \\
$\mathrm{H} 2$ & $\mathrm{FC} \rightarrow \mathrm{BI}$ & 0.394 & $0.014^{*}$ & Supported \\
$\mathrm{H} 3$ & $\mathrm{EE} \rightarrow \mathrm{BI}$ & -0.123 & 0.315 & Not supported \\
$\mathrm{H} 4$ & $\mathrm{SI} \rightarrow \mathrm{BI}$ & -0.076 & 0.277 & Not supported \\
$\mathrm{H} 5$ & $\mathrm{MAG} \rightarrow \mathrm{BI}$ & 0.228 & $0.007^{* *}$ & Supported \\
$\mathrm{H} 6$ & $\mathrm{IN} \rightarrow \mathrm{BI}$ & 0.065 & 0.358 & Not supported \\
$\mathrm{H} 7$ & $\mathrm{TR} \rightarrow \mathrm{BI}$ & 0.025 & 0.544 & Not supported \\
\hline
\end{tabular}

Significance codes: ${ }^{*}$ at $p<0.05,{ }^{* *}$ at $p<0.01,{ }^{* * *}$ at 0 . Note: $\mathrm{SRW}=$ standardized regression weight, $\mathrm{BI}=$ behavioral intention, $\mathrm{PE}=$ performance expectancy, $\mathrm{EE}=$ effort expectancy, $\mathrm{SI}=$ social influence, $\mathrm{FC}=$ facilitating conditions, TR = trust, MAG = mastery-approach goals, $\mathrm{IN}=$ innovativeness.

The finding of the relationship between performance expectancy and behavioral intention (H1) is consistent with earlier studies on mobile banking [58,59]. For agriculture, studies also found the importance of performance expectancy on the intentions of farmers to adopt decision-support tools, mobile-based communication technologies for agricultural information [60], and SMS agricultural advice [39]. This implies that farmers' intentions to use apps will be strengthened if they believe that the apps will result in greater performance in their daily agricultural activities. Moreover, $66 \%$ of the surveyed farmers selected 'faster way of getting information' from a list of potential benefits of an app.

No significant relationships were observed between behavioral intention and the other constructs, implying that hypotheses $\mathrm{H} 2, \mathrm{H} 4, \mathrm{H} 5$, and $\mathrm{H} 7$ could not be supported, and were not found to predict the behavioral intention to use an app significantly. The lack of effect of effort expectancy implies that farmers might not find the effort required to use the mobile-phone app important in their intention to adopt. This can be partially explained by the ubiquitous presence of cell phones, with $46 \%$ of the sample owning a smartphone (see Table 1). Hence, the ease of use seems of low importance for farmers 
already familiar with apps for instant messaging. As 'connected farmers' in the current study are participants in the same program, it was anticipated that social influence would positively affect behavioral intention to adopt the app, but this was not the case, nor was it the case in a previous study on SMS use [39]. This implies that farmers will not simply adopt a technology because important others (e.g., friends or neighbors) are using it. Similarly, an effect of personal innovativeness was expected, as the farmers willing to participate in the hub were innovative or cooperative leaders who have joined the program voluntarily [45]. However, within this group, no effect of personal innovativeness (H7) on the intention to adopt was revealed. In general, this implies that in this context, the willingness of an individual to try out new technologies does not affect the adoption of the mobile-phone app.

Unlike in previous studies on SMS services [39] and decision-support tools [15] already being launched and used by farmers, trust in this study was not found to be a significant factor. The low influence of trust on intention might be partially explained because, contrary to those studies, the provision channel (e.g., extension agent) promoting the use of the app was not yet implemented fully in the region. This might change when the last version of the mobile-phone app is launched, and the provision channel begins to promote it with the specific features, recommendations, and data-sharing characteristics.

\subsection{Multigroup Analyses}

The assumption of full metric variance was tested, but could not be met. Modification indices were calculated to test for any linear constraints that could be relaxed to improve the model fit while accounting for changes in all the parameters. By leaving two item loadings unconstrained for a non-significant path (SI), acceptable model fits were obtained for the partial metric invariance models (all $\Delta \mathrm{CFI}<0.01$ ). Partial metric invariance is the minimum criterion required [61]. This indicated that the latent variables had the same meaning across groups, and that the SEM analysis could be performed on the pooled sample. Only when configural and partial metric invariance at the measurement model level were established could multigroup analyses be conducted at the structural level. Because no hypotheses were available for the added constructs (IN, TR), the included variables were limited to the ones from UTAUT plus mastery-approach goals (MAG).

Results of the moderator effect of age revealed that performance expectancy is more important for older farmers (Table 6), as it shows a significantly higher effect of performance expectancy on behavioral intention. Similarly, the effect of facilitating conditions was significant only for older farmers. On the contrary, the effect of mastery-approach goals on behavioral intention was significant for younger farmers, but not for older farmers. As for the multigroup analysis, performance expectancy was more important for non-connected farmers (Table 7). The influence of MAG on the intentions of younger and non-connected farmers to adopt sheds light on the type of utilitarian benefit to reach those farmers who are not connected to the hub yet (Table 6). Utility refers to the usefulness or value that consumers experience from a product or service. Examples of utilitarian benefit might be special access to training and capacity-building in their regions. The MAG seems to have an effect only on non-connected farmers, while facilitating conditions seems to have an effect only on connected farmers (Table 7). Therefore, the different groups might need different stimuli for an initial adoption once the app is rolled out. Finally, for new and non-connected participants' engagement, focusing on performance expectancy might be a suitable strategy for initially adopting the app. The results showed that the effect of performance expectancy on behavioral intention was significantly higher for non-connected farmers (Table 7). The standardized regression weights (SRW) revealed that the mastery-approach goal was significant only for non-connected farmers. 
Table 6. Multi-group analysis between younger and older farmers.

\begin{tabular}{cccccc}
\hline \multirow{2}{*}{ Hypothesis } & $\begin{array}{c}\text { Structural } \\
\text { Path }\end{array}$ & \multicolumn{2}{c}{ Younger Farmers } & \multicolumn{2}{c}{ Older Farmers } \\
\cline { 3 - 6 } & SRW & $p$-Value & SRW & $p$-Value \\
\hline H1 & PE $\rightarrow$ BI & 0.469 & $* * *$ & 0.690 & $* * *$ \\
H2 & FC $\rightarrow$ BI & 0.199 & 0.338 & 0.946 & $0.019^{*}$ \\
H3 & EE $\rightarrow$ BI & 0.018 & 0.905 & -0.358 & 0.119 \\
H4 & SI $\rightarrow$ BI & 0.019 & 0.884 & -0.078 & 0.566 \\
H5 & MAG $\rightarrow$ BI & 0.431 & $0.002 * *$ & 0.125 & 0.457 \\
\hline
\end{tabular}

Significance codes: ${ }^{*}$ at $p<0.05,{ }^{* *}$ at $p<0.01,{ }^{* * *}$ at 0 . Note: $\mathrm{SRW}=$ standardized regression weight, $\mathrm{BI}=$ behavioral intention, $\mathrm{PE}=$ performance expectancy, $\mathrm{EE}=$ effort expectancy, $\mathrm{SI}=$ social influence, $\mathrm{FC}=\mathrm{facilitating}$ conditions, MAG = mastery-approach goals.

Table 7. Multiple-group analysis between non-connected farmers and connected farmers.

\begin{tabular}{cccccc}
\hline \multirow{2}{*}{ Hypothesis } & \multirow{2}{*}{$\begin{array}{c}\text { Structural } \\
\text { Path }\end{array}$} & \multicolumn{2}{c}{ Non-Connected Farmers } & \multicolumn{2}{c}{ Connected Farmers } \\
\cline { 3 - 6 } & $\mathrm{SE} \rightarrow \mathrm{BI}$ & 0.716 & $\boldsymbol{p}$-Value & SRW & $p$-Value \\
\hline H1 & $\mathrm{PE} \rightarrow * *$ & 0.485 & $* * *$ \\
$\mathrm{H} 2$ & $\mathrm{FC} \rightarrow \mathrm{BI}$ & 0.418 & 0.221 & 0.622 & $0.027^{*}$ \\
H3 & $\mathrm{EE} \rightarrow$ BI & -0.171 & 0.393 & -0.087 & 0.61 \\
$\mathrm{H} 4$ & $\mathrm{SI} \rightarrow \mathrm{BI}$ & -0.258 & 0.079 & 0.079 & 0.462 \\
H6 & $\mathrm{MAG} \rightarrow$ BI & 0.485 & $0.004^{* *}$ & 0.195 & 0.126 \\
\hline
\end{tabular}

Significance codes: ${ }^{*}$ at $p<0.05,{ }^{* *}$ at $p<0.01,{ }^{* * *}$ at 0 . Note: SRW $=$ standardized regression weight, $\mathrm{BI}=$ behavioral intention, $\mathrm{PE}=$ performance expectancy, $\mathrm{EE}=$ effort expectancy, $\mathrm{SI}=$ social influence, $\mathrm{FC}=$ facilitating conditions, MAG = mastery-approach goals.

\section{Implications and Limitations}

\subsection{Implications for Designers, Developers, and Project Managers}

Design-thinking principles have been applied and adapted by CIMMIYT when creating innovation hubs [62]. The prototyping phase is crucial to gain early insights before a solution is launched; the sooner a product is put in front of participants to react to, the faster a value-added solution will be reached [55]. In this study, it was proven that using the UTAUT framework and conducting a SEM analysis are suitable to learn more about the farmers' initial adoption decision. Among the factors revealed, performance expectancy was the strongest predictor of farmers' intention to adopt the proposed agricultural-information app. This signals that in order to promote this kind of mobile-phone app for decision support in the agricultural domain, focusing on the performance expectancy through different approaches, such as user engagement, is worth exploring further. Development of a digital decision-support tool requires early and ongoing interactions with targeted users to map app performance, objectives, and preferences; ensure reliability of scientific input; and optimize the user experience [17]. The study by Harris and Anchora [63] listed challenges and proposed solutions for ICT-based agriculture implementations, such as provision of offline features, timely and relevant advice, and integration of different appropriate delivery channels (e.g., SMS, or interactive voice response (IVR)). The rapid changes in these technologies also change the way that decision-support systems are designed and used. Therefore, researchers need to adapt and extend current adoption models such as the UTAUT and further integrate socio-psychological approaches. For future phases, the continuous application of farmer-centered design that connects with their needs might tackle observed low user adoption, and can increase the chances of launching a successful decision-support service.

Moreover, similar to the "facilitating conditions" construct, previous studies had highlighted the importance of interoperability and compatibility with existing infrastructures (i.e., considering the existing information ecosystem of farmers). In this respect, a mobile-phone app can be integrated, for example, with previous efforts such as the SMS service MasAgro Móvil, which uses the Extensio platform (previously Esoko) to send text 
messages to the hub network with information about prices, weather, and general advice on conservation agriculture practices [45]. Other existing information channels that could be integrated are through fertilizer distributors, social media, or instant-messaging apps and groups. Consideration of the existing, mostly informal settings, and further building on them can increase the possibilities for the adoption of solutions [64].

Given that performance expectancy and facilitating conditions significantly predicted farmers' behavioral intention to adopt the studied app, project managers might ensure that the app offers utilitarian benefits to the farmers, such as actual payment in phone credits [13], and that the technical infrastructure exists to help them to use it. Examples of this are the offline features being developed by AgroTutor's developers to cope with unreliable Internet connections in rural areas and the potential support of extension agents in early stages of usage. Moreover, the difference in the importance of mastery-approach goals (MAG) between farmers connected and not connected to the hub indicates a heterogeneity level of farmers' profiles, even in the same region. Hence, different utilitarian benefits need to be designed to promote adoption in each group. Another enabling environment element is mutual trust, which is considered a best practice despite not being observed in the present work. This is already the case for the innovation hubs, but special attention needs to be taken when bringing new stakeholders to the initiative by not only working with local institutes that already have been accepted, but also stimulating them to co-design the app, which could be a way to establish initial trust between farmers and the initiative. For example, the co-creation of value has proved insightful to understand bottom-of-the-pyramid market dynamics in countries like Bangladesh [65].

\subsection{Limitations}

Despite its contributions to aspects that are important for farmers to adopt a mobilephone app to provide agricultural-related information about crops, some limitations merit discussion. First, the factors important to technology adoption might differ from location to location, so assessing the validity of this model with farmers across different cultures both in developed and developing countries would be theoretically and practically useful. By the same token, our findings are specific to a certain part of Mexico, and the context can be very different in other areas (e.g., areas with lower literacy and less smartphone adoption). Therefore, care must be taken before generalizing to other geographies with other ICT infrastructures. Moreover, the study does not claim to statistically represent farmers in Mexico (neither in terms of gender, nor geographically). It would be interesting to test the model with more female farmers and in other parts of Mexico. Second, since most of the farmers in this study had not used the mobile-phone app, we did not examine the effect of behavioral intention on the use behavior. Therefore, it is recommended that future research include the examination of the effect of behavioral intention on farmers' actual use behavior. Additional research would also allow an assessment of whether the importance of the constructs would change over time or contexts. For example, the effect of trust on farmers' behavioral intention to use the mobile-phone app might become important when the information is being shared with particular organizations, including companies, along with the perceived risk associated with use $[38,66]$. Data-sharing perceptions then possibly become a crucial issue that warrants further study.

Another potential limitation of this study was its focus on a specific app [18]. However, because the study highlighted the underlying intention to adopt drivers rather than the app content/functionalities; our findings could be applied to other non-commercial apps that provide precision agriculture services to smallholders in developing countries. Studies investigating perceived effectiveness and actual adoption of decision support systems are recommended.

\section{Conclusions}

Agricultural mobile-phone applications can provide tailor-made agronomic advice to small-scale farmers, who are often excluded from precision agriculture developments, while 
at the same time can contribute to citizen-science applications that promote sustainable agricultural intensification. Nevertheless, research on the initial adoption decision of agricultural apps in the region of Central and Latin America is limited. In this study, we extended the commonly used UTAUT framework to reveal the main behavioral aspects of Mexican farmers' intention to adopt agricultural apps, including understudied farmers' intrinsic motivations. Performance expectancy was found to be the strongest predictor of farmers' intention to adopt an app to provide agricultural information. This highlights the importance of understanding the benefits perceived by farmers. Thus, managers of agricultural projects aiming to deploy mobile-phone apps need to ensure that their use for data collection offers benefits to farmers, such as mobile credit compensations.

Mastery-approach goals (MAG) were found to be significant, and revealed a baseline of farmers' intrinsic motivation (why they are motivated to use it in the first place) independently of the content of the application. This is of special interest in the initial decision to adopt, with their readiness to learn and master the use of an app providing agricultural innovation. These results motivate us to further explore how non-financial incentives, such as access to training during the app's roll-out might promote its uptake. In addition, younger farmers with a mastery goal orientation can also be targeted in early stages of the app's roll-out, as they are expected to use the mobile-phone app to acquire new skills and knowledge. The app then needs to be accompanied by facilitating conditions and basic conditions, such as access to a smartphone and reliable Internet access. It was revealed that performance expectancy was important for farmers connected and non-connected to the innovation hubs, and for both older and younger farmers. According to the results of the study, the 'connectedness to an innovation hub' in the region has a moderator effect on the intention to adopt. Future research should focus on ways to complementarily assess the farmers' perception of the enabling innovation environment relevant to research-anddevelopment efforts. For example, research in the areas of the Agricultural Innovation System can be a way forward. Finally, the study should be validated and extended to other geographical areas in Mexico and Latin America, since the magnitude of factors could differ, and it is important to consider the user engagement of farmers in these regions.

Author Contributions: Conceptualization, J.M.-M., J.T.-C., A.G.-M., D.T.G., S.S.; Data curation, J.M.-M.; Formal analysis, J.M.-M.; Funding acquisition, A.G.-M., S.S.; Investigation, J.M.-M., N.V.; Methodology, J.M.-M.; Project administration, J.M.-M., N.V.; Resources, A.G.-M.; Supervision, N.V., B.G., S.S.; Writing—original draft, J.M.-M.; Writing—review and editing, J.M.-M., N.V., D.T.G., B.G., S.S. All authors have read and agreed to the published version of the manuscript.

Funding: The survey work was part of the "MasAgro Productor/Guanajuato" project, made possible by the generous support of the government of Mexico through SADER and the State Government of Guanajuato through the SDAyR. The survey was also part of the CGIAR Research Program on Maize (MAIZE) and the CGIAR Research Program on Wheat (WHEAT) with generous support from donors, which include foundations; the governments of Australia, Belgium, Canada, China, France, India, Japan, Korea, Mexico, Netherlands, New Zealand, Norway, Sweden, Switzerland, the UK, and the US; and the World Bank. Any opinions, findings, conclusions, or recommendations expressed in this publication are those of the authors and do not necessarily reflect the view of the donors mentioned previously. The first author is awarded with a CONACYT scholarship provided by the Mexican government.

Institutional Review Board Statement: Ethical review and approval were waived for this study, because no sensitive, personal data or geo localization were collected from individuals. Best practices to collect, anonymous treatment and process of the data were followed according to Ghent University guidelines concerning ethics in research.

Informed Consent Statement: Informed verbal consent was obtained from all participants in this study. The option to withdraw the interview at any time was provided.

Data Availability Statement: Data available on request. The data presented in this study are available on request from the corresponding author. The data are not publicly available due to its preparation in a suitable open access repository according to CIMMYT best practices. 
Acknowledgments: The authors are grateful to the CIMMYT staff for the opportunity given to the first author to conduct a research stage. Special thanks are given to the surveyed farmers for their participation and to the team from MasAgro Guanajuato (Erick, Amador, and extensionists) for their help with the logistics.

Conflicts of Interest: The authors declare no conflict of interest. The funders had no role in the design of the study; in the collection, analyses, or interpretation of data; in the writing of the manuscript; or in the decision to publish the results.

\section{Appendix A}

Questionnaire to assess a mobile phone app technology acceptance of farmers in Guanajuato.

The main purpose of this survey is to assess a mobile app technology acceptance of farmers as a data provision tool to provide agricultural information and their preferences around the use.

\section{Background information (filled by enumerator) \\ Date: Municipality: Village:}

\section{Introduction}

[Introduce yourself] Thanks a lot for the time you are taking today. This survey has the objective to evaluate the factors that affect the potential willingness to use and the stated preferences when using a mobile phone app for agricultural purposes. The results will be used only for research purposes and I assure your confidentiality. This survey will be divided into 3 parts. I will need to register the data on my cell phone, I hope it does not bother you. In the first part I will ask you some general questions, in the 2nd part I will give you some options to choose from. The third part contains questions about your intention to use (or not) an application. Thanks again for your time. Do you have any question so far?

\section{General information of the respondent}

How old are you?: years

Gender: [] Male [] Female

Marital status? [] Married [] Single [] Co habitation [] Other

Do you have any children (sons or daughters) from the age of 18-35? [] Yes [] No What is your educational level?

[] None [] Primary school [] Secondary school [] Higher education [] Other, specify

Can you read and write? [] Yes [] No

\section{Farming system(s)}

What are your main sources of livelihood and income?

[] Farming (grain) [] Livestock [] Horticulture [] Other off-farm income

What is the total land size of your sowed plot(s)? (ha) ha

How many crops do you usually sow (average situation)?

Do you have any agricultural contract nowadays? [] Yes [] No $\mathrm{P} / \mathrm{V}: \mathrm{O} / \mathrm{I}:$

Are you the owner of the farm or plots? [] Yes [] No Around how many hectares you own? ha

\section{Extensionist services}

Are you a member of the Innovation Hub (MasAgro)? [] Yes [] No

For how many years have you been in contacted with the Innovation Hub? years

Do you receive any additional extensionism service? [] Yes [] No

How frequent did you receive advices from extensions' agents?

[] Never [] every 3 days [] Weekly [] Monthly [] Bi-monthly [] Once every 6 months

Which are your main sources of information to get agricultural (agronomic) information and advices?

[] Extension agents

[] Organisations

[] Direct communications with neighbours

[] Meetings \& Events 
[] TV/Radio/Newspaper

[] Social media

[] Mobile phone based (SMS, Whatsapp groups, Ag apps)

[] Internet (websites)

Do you normally follow what the previous sources advise you? [] Yes [] No

If No, Which will be the reasons for not following the advices provided by your main sources?

[] Not specific to my location

[] Inappropriate availability of quality inputs (seed, pesticides and fertilizers)

[] Poor or no access to soil and/or water testing

[] Poor access to markets

[] Financial constraints

[] Other issues

From the following list of information on agriculture, what information do you find most useful? (max 3)

[] Weather

[] Input use in general (fertilizers, seeds, agro-chemicals)

[] Yields prediction

[] Income and costs from nearby farms

[] Advise to manage pest, diseases and weeds

[] Prices forecasting

6. Network and Mobile phone info.

Which is the approximate distance to nearest good mobile network place (walking distance in minutes)?

[] 0 min (on my own farm/home)

[] $5-15 \mathrm{~min}$.

[] $30 \mathrm{~min}-60 \mathrm{~min}$

[] more than $1 \mathrm{~h}$

Mobile phone ownership: [] Yes [] No

On average, how much did you spend per month in mobile (Mexican pesos/month)?

Which kind of phone? [] Smart phone [] Mid-range Phone [] Basic Phone

For how long, have you own a smart phone?

On a day, around how much time do you spend on your smart phone on average? minutes

What are the main benefits you perceive about obtaining agricultural information on cell phones?

[] None

[] It is a fast way of getting information

[] Better connected to markets

[] Better prices

[] Increasing yields

[] Other

7. Familiarity with existing agricultural extension apps.

Do you know any existing apps for agricultural purpose in the region? [] Yes [] No

If you remember the name, could you please provide it?

Will you be willing to use them? Yes [] No []

If no, why you would not use it?

[] I do not have a phone

[] I do not have financial means to top up my mobile phone

[] I do not know how to use it

[] I am not interested

[] Other 


\section{Scripted intro.}

First, I would like to thank you once again for participating in this interview. The questions I ask you after this point are related to the mobile phone or smartphone, mainly the use of your mobile phone to consult and receive agronomic information. Thank you for your valuable time and we will proceed to the questions. Please indicate the degree to which you agree with each statement by using the scale 1 (Disagree strongly), (4) being neutral, to 7 (Agree strongly).

\section{Thanks and ask if anything is wanted to be added}

\section{Appendix B}

\begin{tabular}{|c|c|c|c|}
\hline Constructs & Items & ID & Source \\
\hline Behavioral Intention (BI) & $\begin{array}{l}\text {-In the future, I intend to use or } \\
\text { continue using mobile phone apps that } \\
\text { provide me with any agronomic } \\
\text { information. } \\
\text {-I will always try to use mobile phone } \\
\text { apps that provide me agronomic } \\
\text { information, in my daily life. } \\
\text {-I plan to use or continue using mobile } \\
\text { phone apps frequently that provide } \\
\text { agronomic information. }\end{array}$ & BI3 & {$[27,29,39]$} \\
\hline Performance expectancy (PE) & $\begin{array}{l}\text {-I find agronomic advices provided } \\
\text { through a mobile phone (cellphone), } \\
\text { useful in my daily life. } \\
\text {-Using a mobile phone (cellphone) app } \\
\text { helps me to increase my productivity. } \\
\text {-Using a mobile phone (cellphone) app } \\
\text { on a mobile phone (cellphone) helps me } \\
\text { to accomplish things faster on my plots. } \\
\text {-Using a mobile phone (cellphone) } \\
\text { increases my possibilities of achieving } \\
\text { higher crop yields. }\end{array}$ & PE2 & {$[27,29,39]$} \\
\hline Effort expectancy (EE) & $\begin{array}{l}\text {-Learning how to use a mobile phone } \\
\text { (cellphone)' app is easy for me. } \\
\text {-My interaction with a mobile phone } \\
\text { (cellphone)' app is clear and } \\
\text { comprehensive. } \\
\text {-I find the mobile phone (cellphone)' } \\
\text { apps easy to use. } \\
\text {-It is easy for me to become skilful at } \\
\text { using mobile phone (cellphone)' apps }\end{array}$ & EE3 & {$[27,29,39]$} \\
\hline Social influence (SI) & $\begin{array}{l}\text {-People whose opinions I value, prefer } \\
\text { that I use mobile phone (cellphone) } \\
\text { apps } \\
\text {-People who influences how I behave } \\
\text { think I should use mobile phone } \\
\text { (cellphone) apps } \\
\text {-People who are important to me think } \\
\text { that I should use mobile phone } \\
\text { (cellphone) apps } \\
\text {-People who are important to me } \\
\text { would use mobile phone (cellphone) } \\
\text { apps themselves. }\end{array}$ & SI1 & {$[27,29,39]$} \\
\hline
\end{tabular}




\begin{tabular}{|c|c|c|c|}
\hline Constructs & Items & ID & Source \\
\hline Facilitating conditions (FC) & $\begin{array}{l}\text {-I have the necessary resources to use a } \\
\text { mobile phone (cellphone) app. } \\
\text {-I have the necessary knowledge to use } \\
\text { a mobile phone (cellphone) app. } \\
\text {-The mobile phone (cellphone) apps are } \\
\text { compatible with other technologies I } \\
\text { use } \\
\text {-I can get help from others when I have } \\
\text { difficulties using a mobile phone } \\
\text { (cellphone) }\end{array}$ & $\begin{array}{l}\text { FC1 } \\
\text { FC2 }\end{array}$ & {$[27,29,39]$} \\
\hline $\begin{array}{c}\text { Trust (TR) } \\
\text { Trust in extension (app provider) } \\
\text { vs. project }\end{array}$ & $\begin{array}{l}\text {-The extension services provider is very } \\
\text { concerned about my crop(s) } \\
\text { production. } \\
\text {-My needs and desires are very } \\
\text { important to the extension services } \\
\text { provider } \\
\text {-The extension services provider would } \\
\text { not knowingly do anything to hurt me } \\
\text {-The extension services provider really } \\
\text { looks out for what is important to me } \\
\text { The extension services provider will go } \\
\text { out of its way to help me }\end{array}$ & $\begin{array}{l}\text { TR3 } \\
\text { TR4 } \\
\text { TR5 }\end{array}$ & {$[39,40]$} \\
\hline $\begin{array}{c}\text { Mastery-approach goals } \\
\text { (MAG) } \\
\text { MAG in the actual app vs. app' } \\
\text { advices }\end{array}$ & $\begin{array}{l}\text {-I want to learn as much as possible } \\
\text { about an agricultural mobile phone } \\
\text { (cell phone) app. } \\
\text {-It is important for me to completely } \\
\text { understand the recommendations } \\
\text { provided by the agricultural mobile } \\
\text { phone (cell phone) app. } \\
\text {-I desire to completely master the use of } \\
\text { the agricultural mobile phone (cell } \\
\text { phone) app. }\end{array}$ & MAG2 & {$[39,67]$} \\
\hline Innovativeness (IN) & $\begin{array}{l}\text {-If I heard about a new technology, I } \\
\text { would look for ways to experiment } \\
\text { with it. } \\
\text {-Among my peers, I am usually the first } \\
\text { to explore new gadgets and } \\
\text { technologies. } \\
\text {-I like to experiment with new } \\
\text { technologies. }\end{array}$ & IN3 & {$[39,68]$} \\
\hline
\end{tabular}

\section{Appendix C}

To assess configural invariance, unconstrained multi-group measurement models, which allow factor loadings to vary across two groups (i.e., between MasAgro-connected farmers and non-connected farmers and between younger and older farmers) were developed. The model fit for the configural invariance between younger and older farmers was satisfactory $(\mathrm{CMIN} / \mathrm{DF}=2.198 ; \mathrm{CFI}=0.933$; $\mathrm{RMSEA}=0.078)$, and that between connected and non-connected farmers was also satisfactory $(\mathrm{CMIN} / \mathrm{DF}=2.403 ; \mathrm{CFI}=0.927$; RMSEA $=0.062$ ) [55]. This implied that the models fit both groups well and configural invariance was met.

To assess metric invariance, fully constrained measurement models that constrain the measurement weights (i.e., factor loadings) for each measured variable to be equal for the two groups (i.e., between younger and older farmers and between connected and non-connected farmers) were developed, but could not be met. Modification indices were estimated to explore for any linear constraints that could be relaxed to improve the model 
fits while accounting for changes in all the parameters. By leaving two item loadings unconstrained for a non-significant path (SI), acceptable model fits were obtained for the partial metric invariance models (all $\Delta \mathrm{CFI}<0.01$ ). Partial metric invariance is the minimum criterion required to validate the analysis [61]. This indicated that the latent variables had the same meaning across groups, and that SEM analysis could be performed on the sample.

\section{References}

1. Gebbers, R.; Adamchuk, V.I. Precision Agriculture and Food Security. Science 2010, 327, 828-831. [CrossRef] [PubMed]

2. Li, Z.; Taylor, J.; Frewer, L.; Zhao, C.; Yang, G.; Li, Z.; Liu, Z.; Gaulton, R.; Wicks, D.; Mortimer, H.; et al. A comparative review of the state and advancement of Site-Specific Crop Management in the UK and China. Front. Agric. Sci. Eng. 2019, 6, 116-136. [CrossRef]

3. Lowenberg-DeBoer, J.; Erickson, B. Setting the Record Straight on Precision Agriculture Adoption. Agron. J. 2019, 111, 1552-1569. [CrossRef]

4. Torky, M.; Hassanein, A.E. Integrating blockchain and the internet of things in precision agriculture: Analysis, opportunities, and challenges. Comput. Electron. Agric. 2020, 178, 105476. [CrossRef]

5. Mendes, J.; Pinho, T.M.; Neves dos Santos, F.; Sousa, J.J.; Peres, E.; Boaventura-Cunha, J.; Cunha, M.; Morais, R. Smartphone Applications Targeting Precision Agriculture Practices-A Systematic Review. Agronomy 2020, 10, 855. [CrossRef]

6. Bhakta, I.; Phadikar, S.; Majumder, K. State-of-the-art technologies in precision agriculture: A systematic review. J. Sci. Food Agric. 2019, 99, 4878-4888. [CrossRef] [PubMed]

7. Lajoie-O'Malley, A.; Bronson, K.; van der Burg, S.; Klerkx, L. The future(s) of digital agriculture and sustainable food systems: An analysis of high-level policy documents. Ecosyst. Serv. 2020, 45, 101183. [CrossRef]

8. Villa-Henriksen, A.; Edwards, G.T.C.; Pesonen, L.A.; Green, O.; Sørensen, C.A.G. Internet of Things in arable farming: Implementation, applications, challenges and potential. Biosyst. Eng. 2020, 191, 60-84. [CrossRef]

9. Chipidza, W.; Leidner, D. A review of the ICT-enabled development literature: Towards a power parity theory of ICT4D. J. Strateg. Inf. Syst. 2019, 28, 145-174. [CrossRef]

10. Mittal, S.; Mehar, M. How mobile phones contribute to growth of small farmers? evidence from India. Q. J. Int. Agric. 2012, 51, 227-244. [CrossRef]

11. Jordan, R.; Eudoxie, G.; Maharaj, K.; Belfon, R.; Bernard, M. AgriMaps: Improving site-specific land management through mobile maps. Comput. Electron. Agric. 2016, 123, 292-296. [CrossRef]

12. Eitzinger, A.; Cock, J.; Atzmanstorfer, K.; Binder, C.R.; Läderach, P.; Bonilla-Findji, O.; Bartling, M.; Mwongera, C.; Zurita, L.; Jarvis, A. GeoFarmer: A monitoring and feedback system for agricultural development projects. Comput. Electron. Agric. 2019, 158, 109-121. [CrossRef] [PubMed]

13. Minet, J.; Curnel, Y.; Gobin, A.; Goffart, J.-P.; Mélard, F.; Tychon, B.; Wellens, J.; Defourny, P. Crowdsourcing for agricultural applications: A review of uses and opportunities for a farmsourcing approach. Comput. Electron. Agric. 2017, 142, 126-138. [CrossRef]

14. Beza, E.; Steinke, J.; Van Etten, J.; Reidsma, P.; Fadda, C.; Mittra, S.; Mathur, P.; Kooistra, L. What are the prospects for citizen science in agriculture? Evidence from three continents on motivation and mobile telephone use of resource-poor farmers. PLoS ONE 2017, 12, e0175700. [CrossRef]

15. Rose, D.C.; Sutherland, W.J.; Parker, C.; Lobley, M.; Winter, M.; Morris, C.; Twining, S.; Ffoulkes, C.; Amano, T.; Dicks, L.V. Decision support tools for agriculture: Towards effective design and delivery. Agric. Syst. 2016, 149, 165-174. [CrossRef]

16. Lindblom, J.; Lundström, C.; Ljung, M. Next Generation Decision Support Systems for Farmers: Sustainable Agriculture through Sustainable IT. In Proceedings of the 11th European IFSA Symposium, Berlin, Germany, 1-4 April 2014; pp. 49-57.

17. Eichler Inwood, S.E.; Dale, V.H. State of apps targeting management for sustainability of agricultural landscapes. A review. Agron. Sustain. Dev. 2019, 39. [CrossRef]

18. GSMA The mAgri Design Toolkit. User-Centered Design for Mobile Agriculture. Available online: https://www.gsma.com/ mobilefordevelopment/agritech/magri-design-toolkit/ (accessed on 15 November 2020).

19. Michels, M.; Bonke, V.; Musshoff, O. Understanding the adoption of smartphone apps in crop protection. Precis. Agric. 2020, 1-18. [CrossRef]

20. Trendov, N.M.; Varas, S.; Zeng, M. Digital Technologies in Agriculture and Rural Areas; Briefing Paper: Rome, Italy, 2019.

21. Emeana, E.M.; Trenchard, L.; Dehnen-Schmutz, K. The revolution of mobile phone-enabled services for agricultural development (m-Agri services) in Africa: The challenges for sustainability. Sustainability 2020, 12, 485. [CrossRef]

22. Kabbiri, R.; Dora, M.; Kumar, V.; Elepu, G.; Gellynck, X. Mobile phone adoption in agri-food sector: Are farmers in Sub-Saharan Africa connected? Technol. Forecast. Soc. Chang. 2018, 131, 253-261. [CrossRef]

23. Mittal, S.; Mehar, M.; Hariharan, V.K. Information and communication technologies for strengthening extension services to reach the last mile in India. In Agricultural Extension Reforms in South Asia; Elsevier: Amsterdam, The Netherlands, 2019 ; pp. $255-274$.

24. Steinke, J.; van Etten, J.; Müller, A.; Ortiz-Crespo, B.; van de Gevel, J.; Silvestri, S.; Priebe, J. Tapping the full potential of the digital revolution for agricultural extension: An emerging innovation agenda. Int. J. Agric. Sustain. 2020, 1-17. [CrossRef]

25. Wyche, S.; Steinfield, C. Why Don't Farmers Use Cell Phones to Access Market Prices? Technology Affordances and Barriers to Market Information Services Adoption in Rural Kenya. Inf. Technol. Dev. 2016, 22, 320-333. [CrossRef] 
26. Laso Bayas, J.C.; Gardeazabal, A.; Karner, M.; Folberth, C.; Vargas, L.; Skalský, R.; Balkovič, J.; Subash, A.; Saad, M.; Delerce, S.; et al. AgroTutor: A Mobile Phone Application Supporting Sustainable Agricultural Intensification. Sustainability 2020, 12, 9309. [CrossRef]

27. Venkatesh; Morris; Davis; Davis User Acceptance of Information Technology: Toward a Unified View. MIS Q. 2003, 27, 425. [CrossRef]

28. Williams, M.D.; Rana, N.P.; Dwivedi, Y.K. The unified theory of acceptance and use of technology (UTAUT): A literature review. J. Enterp. Inf. Manag. 2015, 28, 443-488. [CrossRef]

29. Venkatesh; Thong; Xu Consumer Acceptance and Use of Information Technology: Extending the Unified Theory of Acceptance and Use of Technology. MIS Q. 2012, 36, 157. [CrossRef]

30. Min, S.; So, K.K.F.; Jeong, M. Consumer adoption of the Uber mobile application: Insights from diffusion of innovation theory and technology acceptance model. J. Travel Tour. Mark. 2018, 36, 770-783. [CrossRef]

31. Dwivedi, Y.K.; Rana, N.P.; Jeyaraj, A.; Clement, M.; Williams, M.D. Re-examining the Unified Theory of Acceptance and Use of Technology (UTAUT): Towards a Revised Theoretical Model. Inf. Syst. Front. 2019, 21, 719-734. [CrossRef]

32. Rogers, E.M. Diffusion of preventive innovations. Addict. Behav. 2002, 27, 989-993. [CrossRef]

33. Rogers, E.M.; Shoemaker, F.F. Communication of Innovations: A Cross-Cultural Approach, 2nd ed.; The Free Press: New York, NY, USA, 1971.

34. Agarwal, R.; Prasad, J. A Conceptual and Operational Definition of Personal Innovativeness in the Domain of Information Technology. Inf. Syst. Res. 1998, 9, 204-215. [CrossRef]

35. Baganzi, R.; Lau, A.K.W. Examining Trust and Risk in Mobile Money Acceptance in Uganda. Sustainability 2017, 9, 2233. [CrossRef]

36. Slade, E.L.; Dwivedi, Y.K.; Piercy, N.C.; Williams, M.D. Modeling Consumers' Adoption Intentions of Remote Mobile Payments in the United Kingdom: Extending UTAUT with Innovativeness, Risk, and Trust. Psychol. Mark. 2015, 24, 763-785. [CrossRef]

37. Duane, A.; O'Reilly, P.; Andreev, P. Realising M-Payments: Modelling consumers' willingness to M-pay using Smart Phones. Behav. Inf. Technol. 2014, 33, 318-334. [CrossRef]

38. Bankole, F.O.; Bankole, O.O. The effects of cultural dimension on ICT innovation: Empirical analysis of mobile phone services. Telemat. Informatics 2017, 34, 490-505. [CrossRef]

39. Beza, E.; Reidsma, P.; Poortvliet, P.M.; Belay, M.M.; Bijen, B.S.; Kooistra, L. Exploring farmers' intentions to adopt mobile Short Message Service (SMS) for citizen science in agriculture. Comput. Electron. Agric. 2018, 151, 295-310. [CrossRef]

40. Mayer, R.C.; Davis, J.H. The effect of the performance appraisal system on trust for management: A field quasi-experiment. J. Appl. Psychol. 1999, 84, 123-136. [CrossRef]

41. Nicholls, J.G. Achievement motivation: Conceptions of ability, subjective experience, task choice, and performance. Psychol. Rev. 1984, 91, 328-346. [CrossRef]

42. Yi, M.Y.; Hwang, Y. Predicting the use of web-based information systems: Self-efficacy, enjoyment, learning goal orientation, and the technology acceptance model. Int. J. Hum. Comput. Stud. 2003, 59, 431-449. [CrossRef]

43. Day, E.A.; Radosevich, D.J.; Chasteen, C.S. Construct- and criterion-related validity of four commonly used goal orientation instruments. Contemp. Educ. Psychol. 2003, 28, 434-464. [CrossRef]

44. Charatsari, C.; Lioutas, E.D.; Koutsouris, A. Farmers' motivational orientation toward participation in competence development projects: A self-determination theory perspective. J. Agric. Educ. Ext. 2017, 23, 105-120. [CrossRef]

45. Deschamps-Solorzano, L. Cosechando Innovación: Un Modelo de México para el Mundo; Instituto Interamericano de Cooperación para la Agricultura (IICA): Mexico City, Mexico, 2016; ISBN 9789292486433.

46. OECD-FAO. Chapter 3. Cereals. In Agricultural Outlook 2018-2027; Projections by Commodity (Online Only); OECD Publishing: Paris, France; Food and Agriculture Organization of the United Nations: Rome, Italy, 2018; pp. 109-126. Available online: http:/ / www.fao.org/3/i9166e/i9166e_Chapter3_Cereals.pdf (accessed on 15 November 2020).

47. FAO. Cereals, Starchy Roots and Other Foods High in Carbohydrates. Available online: http://www.fao.org/3/w0073s/w007 3s0u.htm (accessed on 15 November 2020).

48. Avance de Siembras por Cultivo. Available online: http://infosiap.siap.gob.mx:8080/agricola_siap_gobmx/AvanceNacionalCultivo. do (accessed on 20 November 2019).

49. Camacho-Villa, T.C.; Almekinders, C.; Hellin, J.; Eulalia Martinez-Cruz, T.; Rendon-Medel, R.; Guevara-Hernández, F.; Beuchelt, T.D.; Govaerts, B. The evolution of the MasAgro hubs: Responsiveness and serendipity as drivers of agricultural innovation in a dynamic and heterogeneous context. J. Agric. Educ. Ext. 2016, 22, 455-470. [CrossRef]

50. Hair, J.F.; Black, W.C.; Babin, B.J.; Anderson, R.E. Multivariate Data Analysis, 7th ed.; Pearson Educated Limited: New York, NY, USA, 2014; ISBN 978-1-292-02190-4.

51. Rosseel, Y. lavaan: An R Package for Structural Equation Modeling. J. Stat. Softw. 2012, 48. [CrossRef]

52. Hu, L.-T.; Bentler, P.M. Structural Equation Modeling: A Multidisciplinary Journal Cutoff criteria for fit indexes in covariance structure analysis: Conventional criteria versus new alternatives. Multidiscip. J. 2009, 6, 1-55. [CrossRef]

53. Fornell, C.; Larcker, D.F. Evaluating Structural Equation Models with Unobservable Variables and Measurement Error. J. Mark. Res. 1981, 18, 39-50. [CrossRef]

54. Steenkamp, J.E.M.; Baumgartner, H. Assessing Measurement Invariance in Cross-National Consumer Research. J. Consum. Res. 1998, 25, 78-107. [CrossRef] 
55. Milfont, T.L.; Fischer, R. Testing measurement invariance across groups: Applications in cross-cultural research. Int. J. Psychol. Res. 2010, 3, 111. [CrossRef]

56. Cook, D.A.; Artino, A.R. Motivation to learn: An overview of contemporary theories. Med. Educ. 2016, 50, 997-1014. [CrossRef] [PubMed]

57. INEGI. Encuesta Nacional Agropecuaria 2017 y 2019/National Agricultural Survey. Available online: https:/ /www.inegi.org. $\mathrm{mx} /$ programas/ena/2017/ (accessed on 15 November 2020).

58. Baptista, G.; Oliveira, T. Understanding mobile banking: The unified theory of acceptance and use of technology combined with cultural moderators. Comput. Hum. Behav. 2015, 50, 418-430. [CrossRef]

59. Oliveira, T.; Faria, M.; Thomas, M.A.; Popovič, A. Extending the understanding of mobile banking adoption: When UTAUT meets TTF and ITM. Int. J. Inf. Manag. 2014, 34, 689-703. [CrossRef]

60. Engotoit, B.; Kituyi, G.M.; Moya, M.B. Influence of performance expectancy on commercial farmers' intention to use mobile-based communication technologies for agricultural market information dissemination in Uganda. J. Syst. Inf. Technol. 2016, 18, 346-363. [CrossRef]

61. Vandenberg, R.J.; Lance, C.E. A Review and Synthesis of the Measurement Invariance Literature: Suggestions, Practices, and Recommendations for Organizational Research. Organ. Res. Methods 2000, 3, 4-70. [CrossRef]

62. Liedtka, J.; Salzman, R.; Azer, D. Design Thinking for the Greater Good: Innovation in the Social Sector; Columbia Business School Publishing: New York, NY, USA, 2017; ISBN 9780231179522.

63. Harris, C.G.; Achora, J.C. Designing ICT for Agriculture (ICT4A) Innovations for Smallholder Farmers. In Proceedings of the XIX International Conference on Human Computer Interaction 2018, Palma, Spain, 12-14 September 2018; ACM Press: New York, NY, USA, 2018; pp. 1-9.

64. Doorneweert, B.; Bhan, N.; Kimunyu, W.; Esko, S. The Farmer's Perspective: Bridging the Last Mile to Market; LEI Wageningen UR: Den Haag, The Netherlands, 2014.

65. Dey, A.; Singh, G.; Gupta, A.K. Women and Climate Stress: Role Reversal from Beneficiaries to Expert Participants. World Dev. 2018, 103, 336-359. [CrossRef]

66. Shaikh, A.A.; Karjaluoto, H. Mobile banking adoption: A literature review. Telemat. Inform. 2015, 32, 129-142. [CrossRef]

67. Elliot, A.J.; McGregor, H.A. A $2 \times 2$ achievement goal framework. J. Pers. Soc. Psychol. 2001, 80, 501-519. [CrossRef] [PubMed]

68. Yi, M.Y.; Jackson, J.D.; Park, J.S.; Probst, J.C. Understanding information technology acceptance by individual professionals: Toward an integrative view. Inf. Manag. 2006, 43, 350-363. [CrossRef] 